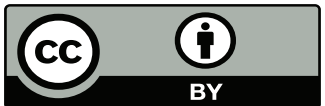

Mikko Karhua

\title{
Utooppinen puhunta alueiden kehittämisessä - raakamekanismia, kaukoarvailua ja satumaakaipuuta
}

\section{Utopian talking about regional development - raw-mechanical, remote-guessing and fantasyland-longing}

This article explores the significance of so-called utopian talk in regional development based on interviews where experts speculate the future of municipalities. This talk can be observed in regional development in the attempts to improve the governance of administratively defined regions like municipalities. Utopian talk denotes a way of speaking about certain phenomena, like regions, by transmitting controversial images concerning the future and present condition of the regions in question that include suggestion proposals. This utopian talk about regions was divided into seven types which each include a specific controversial claim, a distinctive image of the region and a certain suggestion of purpose. Traits that were characteristic to each different type of utopian talk were observed in the interviews of regional development experts. An unspoken utopian content defines the way of talking about the present and the future of regions. This appears, for example, as 'a raw mechanical', 'a remote guessing 'and 'a wonderland longing' utopian talk. Some of the types of utopian talk are more suitable than others for municipal management and planning that relies on expertise. These types of utopian talk are used in planning situations to justify strategic choices.

Keywords: utopian, utopia, region, municipality, talking

\section{Johdanto}

Aluekehittämisessä otetaan kantaa alueiden nykytilaan ja tulevaisuuteen. Nykyisin alueiden tämän hetkisestä ja tulevaisuuden tilanteesta puhutaan moniäänisin ja kirjavin kannanotoin. Tämä johtuu muun muassa alueiden kehittämiseen osallistuvasta entistä monipuolisemmasta joukosta kansainvälisiä, kilpailuhenkisiä ja julkisuushakuisia toimijoita (mm. Lintilä 2016, 98-99). Varsinkin kuntien tulevaisuudesta keskustellaan monilla tavoilla. Värikkäästä puheavaruudesta on erotettavissa toistuvia puhuntatapoja, jotka sisältävät utooppista, parempaan tulevaisuuteen suuntautumisen toivoa. Tällainen utooppinen puhunta kuitenkin liittyy ristiriitoihin ja aiheuttaakin niitä. Siten esitetyt mielikuvat alueiden nykytilasta ja tulevaisuudesta ovat joistakin tai joidenkin arvoista nousevia näkökulmia ja suunnitelmia.

a Johtamisen yksikkö, Vaasan yliopisto, mikko.karhu@uva.fi 
Utopian luonnetta kehittämispuheissa ei ole juurikaan tutkittu, mutta sen ymmärtämistä kaivataan parempia aikoja lupailevien ja taustalla vaanivien riskien kanssa tasapainoilevien puheiden aikakaudella. Utopia esiintyy usein niin arkisissa kuin virallisemmissa yhteyksissä kuten aluekehittämisen asiantuntijoiden kielenkäytössä. Sami Moisio (2012, 43) on luonnehtinut modernin valtion aluehallintorakennetta utooppiseksi. Hannu Katajamäki $(2016,96)$ on arvioinut alueiden hallinnollisten vaihtoehtojen sisältävän ajatuksia, joissa on utooppisia piirteitä. Esimerkit viittaavat utopioiden olevan merkittäviä aluekehittämiselle, mutta jättävät niiden olemuksen arvoitukseksi. Mitä utopiat varsinaisesti merkitsevät, miten ne välittyvät ja kuinka niitä voidaan hyödyntää? Mitä utooppisuus ylipäätänsä tarkoittaa ja miten se tunnistetaan puhuntatavoista, jotta sitä voidaan hyödyntää? Utopiapuheiden roolien ja tyyppien hahmottaminen auttaa ymmärtämään niiden taustamotiiveja kuten vaikuttamispyrkimyksiä, mikä edistää yhteiskunnallisen keskustelun vuorovaikutteisuutta.

Tarkoitukseni on selittää utopioiden ilmenemistapaa ja merkitystä vastaamalla seuraaviin kysymyksiin. Miten utopia voidaan määritellä sitä tarkastelevan tieteenalan (utopiatutkimuksen) mukaan? Millä tavalla utopioiden tuntomerkit eli niin kutsuttu utooppisuus tunnistetaan? Vastaan kysymyksiin perehtymällä utopiatutkimuksen teorioihin, jotta saan yleisen käsityksen ilmiön luonteesta. Selitän utopian ja utooppisuuden eron sekä perustelen utooppisuuden sopivammaksi sanaksi luonnehtimaan yhteiskunnan kehittämistä. Sen jälkeen kuvailen utooppisuuden läsnäoloa kielenkäyttötavoissa. Päätavoite on jaotella utooppisuutta puhuntatapoihin sen tunnistamiseksi ja hyödyntämiseksi aluekehittämisessä. Alueilla tarkoitan aluehallinnollisesti määriteltyjä alueita, kuten kuntia, ja kehittämisellä niiden toiminnan parantamista erilaisilla tavoilla, joihin kuntien hallintokin osallistuu. Suhtaudun aluekehittämiseen näin, koska tutkimusaineisto käsittelee kuntien tulevaisuutta hallinnon kehittämistä painottaen. Johtopäätöksissä arvioin, miten havaitut utooppiset puhuntatavat sopivat kuntien asiantuntijavaltaiseen hallinnointiin.

\section{Utopia ja utooppisuus vastaan antiutopia ja antiutooppisuus}

Utopia tunnetaan parhaiten merkityksissä "olematon paikka", täsmällisesti "ei-paikka" (on = ei, topos = paikka), ja "hyvä paikka", tarkalleen "onnellinen paikka" (eu = onnellinen, topos $=$ paikka). Merkitykset ovat peräisin Thomas Moren (1516) keskiajalla kirjoittamasta teoksesta, joka kertoo fiktiivisestä Utopia-nimisestä saariyhteisöstä. Saaren asukkaat ovat järjestäneet yhteisönsä palvelemaan elämän tarpeita yltäkylläisesti, millä More kritisoi keskiajan kurjuutta (Itkonen-Kaila 1998, 10-15). Teoksen nimen kahden tunnetuimman merkityksen yhdistelmänä utopia usein ymmärretään niin hyväksi paikaksi (eutopos), ettei sitä voida tosiasiassa saavuttaa (outopos) (Claeys \& Sargent 1999, 1; Levitas 2010, 2-3).

Utopian tunnetuimmat merkitykset antavat sen tulkinnalle moniulotteisuutta. Ruth Levitas $(2010,2)$ on todennut utopian tarkoittavan rajautuneesti vain fiktiivisessä kirjallisuudessa kuten Moren teoksessa esitettyä kuvitteellista paikkaa. Laajimmillaan utopia merkitsee mitä tahansa kuviteltavissa olevaa paikkaa, jota ei rajoita kuin mielikuvitus (Levitas 2010, 3-6; Lahtinen 2012, 169-173). Nämä vaihtoehtoiset tavat suhtautua utopiaan perustuvat vasta sen ensimmäiseen merkitykseen olemattomana paikkana, jotka jo antavat sen tulkinnalle laajat ulottuvuudet. Mikä tahansa paikka, joka ei vielä ole olemassa, on siis tulkittavissa utopiaksi ottamatta vielä edes kantaa voiko kyseinen paikka toteutua.

Olemattoman paikan tulkintaskaala levenee entisestään keskusteltaessa, mitkä kuviteltavat asiantilat ovat toteutettavia ja mitkä eivät (mm. Bloch 1986; Geras 2000). Tällöin utopiaksi voidaan tulkita sekä paikat, jotka eivät voi toteutua, että paikat, jotka voivat, mutta eivät vielä ole toteutuneet, jolloin sanaan sisältyy jälleen kaksoismerkitys. Utopialla voidaan tarkoittaa toistaiseksi toteutumatonta maailmaa parantavaa muutosta, jota pidetään realistisena (positiivinen). Sillä voidaan tarkoittaa myös mahdottomaksi nähtyä muutosta, jonka maailmaa parantavaa vaikutusta epäillään (negatiivinen). Tällöin merkitys on antiutooppinen (Levitas 2013, 122). Tulkinnan rajat monipuolistuvat edelleen 
huomioitaessa utopia onnellisena paikkana. Tällöin pohditaan, millaiset paikat ovat mahdollisia ja millaiset eivät, mitä on onnellisuus ja mitkä asiat tekevät paikasta onnellisen (mm. Dima-Laza 2002, 15). Esiintyi utopia missä merkityksessä tahansa, sitä ei ole aina tarkoitus ottaa vakavasti. Utopia voi olla satiirin väline (Lahtinen 2017, 6-7) tai ajatuskoe vaihtoehtoisesta tulevaisuudesta (Suvin 1997, 126-128).

Utopian käsitteen sisältöjä on tarkennettu johdannaiskäsitteillä, joista tärkeimpiin lukeutuvat utooppisuus ja utooppinen ajattelu. (Johnson 2011, 4; Lahtinen 2017, 5-6). Utooppisuutta kuvataan orientaatioksi eli suuntautumiseksi kohti avointa tulevaisuutta, jossa toivotaan tapahtuvan positiivista kehitystä nykyhetkeen verrattuna (Lakkala 2017 , 14). Utooppisuus on myös halua kehittää vallitsevia olosuhteita paremmiksi, olivat ne millaisia tahansa ja perustui kehittäminen millaisiin uskomuksiin hyvänsä. Osa kehittymissuuntautumista on toivo paremmasta, joka on unelmoinnin lähde ja toteuttamisen polttoaine. Pohjimmaisena kehityksen voimana on tarpeiden tyydyttämishalu, joka voi jalostua vahvemmaksi tahdoksi halun tyydyttämiseen (Blochin 1986, 45-46). Esimerkkinä suuntautumisesta parempaan tulevaisuuteen pidetään utooppisia käytänteitä (utopian practice). Ne esittävät tulevaisuuden vastamielikuvina (counter-images) ja vastakäytänteinä (counter-practice), jotka ovat vaihtoehtoja yhteiskunnassa sillä hetkellä vallitseville ajattelu- ja toimintatavoille (Holloway 2010, 236-237; Sargisson \& Sargent 2017).

Utopiat ovat arvoituksellisia, koska kukaan ei voi tyhjentävästi kuvailla maailmaa ja sen mahdollisuuksia. Totuuskäsitykset ovat suhteellisia, monilukuisia ja hankauksessa keskenään, vaikka asettuvatkin sosiaalisen vallan määräämään hierarkiaan, jossa jokin totuuskäsitys voi saavuttaa hetkellisesti hegemonisen aseman ( $\mathrm{mm}$. Williams 2005; Gregory 1996, 213-215). Kuvitteellisen ja tosiasiallisen välinen rajakaan ei ole kiistaton ( $\mathrm{mm}$. Phillips 1993, 185-190; Kymäläinen 2006, 214). Jokainen kuvitteellisesta yhteiskunnasta kertova utopiakirjallisuuden teoskin on syntynyt todellisessa ajassa ja paikassa (Lahtinen 2017, 6) kirjoittajan suhteellisen totuuskäsityksen ohjaamana. Käsitykset nykyhetkestä ja tulevaisuudesta sisältävät jännitteisen aineksen, jossa todellisen ja kuvitteellisen sekä mahdollisen ja mahdottoman suhde on kiistanalainen. Mikään orientaatio parempaan ei ole täysin rationaalista, eikä ankkuroitunut vain vallitseviin olosuhteisiin, vaan suuntautuu jo tuleviin. Yhteiskunnan kehittämistäkin voidaan luonnehtia sekä vallitsevien tosiasioiden tulkitsemiseksi, että pyrkimykseksi päästä niiden yli kohti vieläkin parempaa (vrt. Bloch 1986, 222), jolloin paremman kuvittelu on tärkeässä merkityksessä.

Utooppisuus on ihmistä parempaan tulevaisuuteen ohjaava mielentila, joka sisältää tiedostettuja ja tiedostamattomia olemattoman ja onnellisen paikan elementtejä. Parempaa kohti suuntautumiseen kuuluu tunteita kuten toiveita ja pelkoja sekä mielikuvia tulevasta kehityksestä, jossa nykyhetken puutteista on päästy eroon. Täydellisyyden tavoittelu voi kuulua sen sisältöön (Lahtinen 2002, 169-173; Claeys \& Sargent 1999, 6-13), mutta haaveilu vähänkin valoisammasta tulevaisuudesta, kuten paremmasta yhteiskunnasta, riittää (Sargent 2010, 5; Levitas 2010, 192). Utooppisuuden kohteita nimitetään imaginäärisiksi eli kuvitteellisiksi tiloiksi, joissa korostuu suuntautuminen arvoa kohti (Suvin 1997, 130131). Esimerkki kuvitteellisesta tilasta on mielikuva maailmasta, jossa tasa-arvon ihanne on toteutunut. Mielikuvan ei välttämättä tarvitse jäljitellä tilannetta, jossa arvo on toteutunut ihanteellisesti, vaan se voi olla vaatimattomampi kuvitelma arvon toteutumisesta paremmin.

Utooppisuus voi sisältää epäilyt ja murheet tulevaisuudesta, mutta negatiivisia sisältöjä saatetaan nimittää erikseen antiutooppisuudeksi. Antiutooppisuus on johdettu pahaa tai huonoa paikkaa merkitsevästä utopian vastakäsite dystopiasta, jota antiutopiaksikin kutsutaan (mm. Moylan \& Baccolini 2014, 4-5; Sargent 2010, 21.). Dystopian juuret ovat utopiakirjallisuutta kritisoivassa kirjallisuuslajissa, jossa kuvataan epäonnistunut yhteiskunta (Karhu 2019, 118; Lahtinen 2002, 171). Antiutooppisuuden sisällöstä sekä dystopian ja antiutopian erosta vallitsee erilaisia tulkintoja (ks. Balasopoulos 2006; Jameson 2005, 198201). Utooppisuuden vastakohtakäsitteen voidaan ajatella tarkoittavan pelkojen leimaamaa tulevaisuuteen suuntautumista, jossa uhkakuviin ja riskeihin varautuminen korostuu (Levitas 
2013, 200; Sargent 2010, 103-109). Antiutooppisuus voi tarkoittaa myös utopiavastaisuutta eli pessimististä suhtautumista Thomas Moren klassikkoteoksen kaltaisissa kirjateoksissa esitettyihin onnellisiin paikkoihin tai parempaa tulevaisuutta lupaaviin suunnitelmiin (Jacoby 2005, xiii).

Utooppisuuden ja antiutooppisuuden erottaminen ei tarkoita paremman toivomisen olevan irrallaan huonomman pelkäämisestä, vaikka hetkeksi voidaan ajautua ääripäiden lähelle. Tulevaisuussuuntautuminen on tasapainoilua parempien aikojen toivomisen ja huonompien pelkäämisen välillä tietämättä tarkalleen, mitkä toiveet ja pelot käyvät toteen. Parempaan tulevaisuuteen orientoitumisen taustahäiriönä ovat riskit ja epäonnistumispelot (Levitas 2013, 198-200). Käytänkin termiä utooppisuus utopian sijasta. Utooppisuus ei viittaa yksistään johonkin utopian määritteistä, vaan sisältää sen monia osia. Se kuvaa paremmin tulevaisuuden arvoituksellisuutta ilman utopian ylitulkintavaaraa joko positiivisena mahdollisuutena tai negatiivisena mahdottomuutena (Levitas 2010). Haastatteluaineiston tarkastelussa tarkoitan utooppisuudella kunnista alueina annettuja mielikuvia, joissa niiden nykytila tai tulevaisuus esitetään jonkinlaiseksi.

\section{Utooppisuus kielen mielikuvallisuudessa ja aluekehittämisen puhunnassa}

Utooppisuus on suuntautumista nykyhetkestä odotettuun parempaan tulevaisuuteen, jota leimaa arvoituksellinen tietämättömyys. On monia toivottuja ja ei-toivottuja vaihtoehtoja, jotka voivat toteutua tai jäädä toteutumatta. Tulevaisuuden vaihtoehtojen kuvitteleminen toimittaa neljänlaista niin kutsuttua utopian funktiota eli hyötyä yhteiskunnalle (Levitas 2010, 6, 20, 34). Ne tarjoavat tavoittelemisen arvoisen ihanteen, kritiikkiä nykyolosuhteiden parantamiseksi, motivaation haluttuun muutokseen tai kuvitteellisen pakopaikan ikävältä todellisuudelta. Utopiat herättävät vaihtoehdottomuuden harhasta iskemällä "halkeaman" uskomuksiin, jotka ylläpitävät nykyisiä yhteiskuntarakenteita suojaavia käyttäytymismalleja (Holloway 2010, 6-7).

Utooppisten elementtien tunnistaminen tulevaisuuden vaihtoehdoista edellyttää kielen tarkkailua. Utooppisuus ilmenee ja vaikuttaa todellisuuteen kielen välityksellä. Kieli ymmärretään usein viestintä- ja käsitteellistämisvälineeksi, jolla havaintoja järkeistetään (Karjalainen 2006, 87). Kielellä perustellaan uskomuksia sekä rakennetaan havaintotulkintaa ohjaavaa kehystä (Karjalainen 2006, 87-88; Latvala 2006, 82). Edellä kuvatut utooppisuuden elementit näyttäytyvät kielessä, mutta eivät yleensä paljastu heti. Utopiaa harvoin lausutaan julki siinä pelossa, että se alentaisi uskottavuutta ja saisi näyttämään toiveajattelijalta, koska utopia herkästi mielletään toteutuskelvottomaksi ideaksi (mm. Lakkala 2018, 9). Utopia korvataankin usein sanalla visio, näkymä (Hyyryläinen 2019). Utooppisuus on kielen ominaisuus, eikä pelkästään retorinen. Tutkimusaineistokin osoittaa, että sen luonteeseen kuuluu mahdollinen todellistuminen, jolloin puhuja usein uskoo sanomaansa, vaikka sen toteutuminen olisi epätodennäköistä.

Kielen uskotaan kehittyneen kommunikoinnin ja tiedon jakamisen tehostamisen (Pietilä 2004, 139) lisäksi yksilön ja yhteisön välisen suhteen merkityksellistämiseen ja lujittamiseen (Habermas 1987, 141). Kieli on myös vallan instrumentti, jolla pyritään vaikuttamaan viestinnän kohteisiin. Sanoilla ja teksteillä rakennetaan sosiaalista todellisuutta antamalla puhumisen ja kirjoittamisen kohteesta kuten henkilöstä, ryhmästä, tapahtumasta tai paikasta tietynlainen mielikuva (Foucault 1980; Pietikäinen \& Mäntynen 2009, 14, 26, 52-53, 63.) Kielessä ilmenevät paremman paikan mielikuvat voivat olla itsessään tietynlaisia valtavälineitä. Ne ovat parempaan maailmaan orientoitumisen osasia, joihin sisältyy suostuttelun ja uskottelun tarkoitus (Portolano 2012, 120-125). Sanomiseen sisältyvä utooppisuus ei ole harmitonta, vaan se on kielellä vaikuttamiskeino. Kieleen kuuluva utooppisuus tekee kielellisistä ilmauksista jännitteistä. Kieltä sävyttävät virhetulkinnat ja kyseenalaiset uskomukset, joita ei välttämättä huomata (mm. Luoto 2008, 57; Pylkkö 2013, 31). 
Aluekehittäminen on monella tasolla tapahtuvaa, laaja-alaista, arvolatautunutta ja tulevaisuuteen suuntautuvaa toimintaa, jonka tarkoitus on parantaa alueen nykytilannetta edistämällä sen elinvoimaisuutta esim. rakennetun ympäristön, asukkaiden arjen ja luonnon hyvinvoinnin kautta (mm. Lundström 2017, 4; Linnamaa \& Sotarauta 2000, 26-27). Käytän kuntien kehittämistä esimerkkinä aluekehittämisestä. Kunta on alue, jota kehitetään asukkaiden tarpeiden ja toiveiden suuntaviivoittamana muun muassa kielenkäyttötavoilla (Hyyryläinen, Karhu \& Luoto 2018, 26-27; Luoto \& Karhu 2018, 70-71). Aluekehittämistä tehdään suuressa määrin kielellisellä kommunikaatiolla. Alueiden kehittämisen merkitykset artikuloidaan kielen lausumilla, joita voidaan tarkastella puhekäytänteinä ja -tapoina. Aluekehittäminen on utooppista sisältäessään kiisteltyjä kannanottoja alueiden oletetusta nykytilasta ja toteutumattomasta tulevaisuudesta.

Aluekehittämisessä alueiden nykytilasta ja toivotusta kehityssuunnasta puhutaan luotettavuudeltaan kyseenalaisesti. Luotettavuusongelma voi koskea utopian "outooppista ulottuvuutta" eli onko mielikuvan mukaista aluetta olemassa ja voiko sellainen toteutua. Luotettavuuden kyseenalaisuus voi koskea myös "eutooppista ulottuvuutta" eli millaisen mielikuvan alueesta nykyhetkellä tai tulevaisuudessa annetaan jollain laadullisella mittarilla ja onko siihen luottamista. Näissä puhuntatavoissa väittämä nykyhetkestä tai tulevaisuudesta saatetaan esittää kuin varmana tosiasiana. Puhunta on kuitenkin kuvitteellisuuden värittämää tulkintaa nykyisyydestä ja tulevaisuudesta sekä niiden paremmuudesta tai huonommuudesta vertailukohtaan nähden. Luotettavuusongelmasta huolimatta alueiden kehitystä voidaan ohjata toivottuun suuntaan puhumalla aluemielikuvilla, koska puhunnan suostuttelutarkoitus kykenee vaikuttamaan mielipiteisiin.

Yhteiskuntamaantieteessä katsotaan, että maantieteellisesti määrittyvistä alueista kuten kunnista puhutaan usein mielikuvilla. Mielikuvat vertautuvat utopioihin, koska niissä alueet esitetään toisenlaisina kuin ne ovat joko toivottuina tai ei-toivottuina. Alueiden muuttaminen ei ole mahdollista ilman kehittämisen toivotun lopputuloksen kuvittelua (vrt. Baeten 2002, 141; Kallis \& March 2014, 364). Alueiden kuten valtioiden, maakuntien ja kuntien kehittämisen traditioon kuuluu utooppinen ajattelu (ks. Friedmann 2000, 463). Utooppisessa ajattelussa alueiden nykytilaa ja tulevaisuutta hahmotetaan mielikuvina, jotka pyrkivät jäljittelemään, millaisia alueet ovat ja millaisia niistä tulee, jos esimerkiksi niiden hallinnollisiin kehittämistoimenpiteisiin ryhdytään (mm. Friedmann 2000, 469; Pinder 2013, 35). Mielikuvat aiheuttavat jännitteitä ja sisältävät luotettavuusongelmia. Niiden kuuluukin haastaa vallitsevia ajattelu- ja toimintatapoja ja altistua kritiikille (vrt. Anderson 2006, 691-692; Harvey 2000, 195). Nimitänkin alueista ja niiden kehittämisestä puhunnalla välitettäviä mielikuvia aluemielikuviksi.

\section{Tutkimusmenetelmä ja aineisto}

Tutkimuksen aineisto kerättiin osana Suomen kuntien tulevaisuutta tarkastelevaa tutkimusta (Hyyryläinen, Karhu \& Luoto 2018), jossa haastateltiin kymmentä kunta-alan asiantuntijaa puhelimitse. Haastattelut soveltuvat myös tämän tutkimusartikkelin aineistoiksi, koska niissä käsitellään utooppisuuteen liittyviä aiheita kuten odotuksia tulevaisuuden kehityssuunnista.

Hyödynnän aineiston tutkimiseen laadullista sisältöanalyysia, koska se soveltuu verbaalisen ja kommunikatiivisen tutkimusdatan tarkasteluun (Sarajärvi \& Tuomi 2018; Seitamaa-Hakkarainen 2019). Analyysiäni voi pitää teorialähtöisenä, koska aineiston tutkimisen tarkoitus on lukea esiin utooppisuuden piirteitä haastatteluissa. Teorialähtöisessä sisältöanalyysissä tutkittua ilmiötä lähestytään valmiista teoreettisesta näkökulmasta. Lähtökohtanani ovat utopiatutkimuksen keskeiset teoriat (esim. Levitas 2010; Sargent 2010; Bloch 1986) ja aineistoanalyysiä on tehty asiantuntijoiden litteroitua puhetta lukemalla ja haastateltavien näkökulmia ymmärtäen. Tutkimastani ilmiöstä ei ole aikaisempaa tutkimusta, jossa sovelletaan samoja tutkimusmenetelmiä vastaavaan tarkoitukseen. 
Utooppisuus ja antiutooppisuus ovat erotettavissa toisistaan sisällöllisesti, mutta kielenkäyttötilanteissa jakolinjan vetäminen on hankalampaa. Tämä johtuu todetusta seikasta, ettei tulevaisuussuuntautuminen ole vain yhdenlaista, vaan se on sekoitus useampia samanaikaisia suuntautumistapoja. Kenneth Burke $(1967,16)$ on sanonut ihmisen olevan symbolisia viestintäkeinoja kuten kieliä keksivä, hyödyntävä ja väärinkäyttävä eläin, mikä paljastaa toisen haasteen erotella utooppisuus ja antiutooppisuus kielenkäytössä. Kieli on altis positiivisille ja negatiivisille tulkinnoille. Neutraalitkin väittämät sisältävät molempia. Riippuu monesta asiasta, saako kielenkäyttö kuten puhunta aikaan positiivisen, negatiivisen vai neutraalin tulkinnan. Vaikka kielenkäyttäjä pyrkisi tiettyyn vaikutelmaan, hän ei voi olla varma, miten vastaanottaja tulkitsee sanoja. Kielenkäyttäjä ei myöskään välttämättä kerro kaikkea, eikä miten tahansa, vaan valitsee asiat ja sanat palvelemaan tarkoitusperiään (Portolano 2012, 114-115). Kielen tulkintaan vaikuttavat lisäksi muutkin kuin sanat ja lauserakenteet, sillä eleet, äänensävyt ja ilmeet ovat tärkeä osa viestintää.

Puhekielen kehittyminen tehosti ihmisten viestintää ja tiedon jakamista (Pietilä 2004, 139; Postman 1985, 23), mikä mahdollisti myöhemmin muun muassa järjestelmällisen kirjoitetun kielen keksimisen. Puhe on spontaanimpaa ja epäjohdonmukaisempaa kuin tarkemmin harkittu kirjoitettu kieli (Postman 1985, 25). Tämän vuoksi uskon puhekielen välittävän paremmin utooppisuuden kaltaista ilmiötä kuin kirjoitetun kielen. Puhuessaan itseään ilmaistaan vapaammin muun muassa tutkitun ilmiön kannalta tärkeiden elementtien kuten toiveiden ja pelkojen suhteen toisin kuin kirjoitettaessa, jolloin kieli-ilmaisuja pystytään korjaamaan.

Tarkastelu keskittyy puhekielen tuottamaan ilmiöön puhuntaan eli tapoihin, joilla tietyistä asioista kuulee puhuttavan. Tutkimusta varten haastateltujen asiantuntijoiden puheet alueista ja niiden kehittämisestä ovat esimerkki tietystä puhunnasta. Keskityn vain puheavaruuden sanavalintojen ja lauserakenteiden muodostamiin puhuntatapoihin ja jätän huomioimatta esimerkiksi henkilökohtaiset tarkoitusperät ja ei-kielellisen viestinnän. Puhelimitse kerätty haastattelumateriaali ei sovellu ei-kielellisen viestinnän tutkimiseen paitsi liian tulkinnanvaraisten äänensävyjen perusteella. Selittäessäni seitsemää utooppista puhuntatapaa, tuon esille kussakin läsnä olevan piirteen, joka antaa syytä epäillä puhunnan luotettavuutta ja avaa antiutooppisen tulkinnan mahdollisuuden (mm. Jacoby 2005, 48-51; Locke 2017). Kuvailen lisäksi utooppisten puhuntatapojen aluemielikuvien ja suostuttelutarkoitusten vastaavia piirteitä.

Utooppisen puhunnan seitsemän tapaa perustuvat utooppisuutta määrittelevien teorioiden ja haastatteluaineiston tutkimiseen. Kussakin puhuntatavassa on niiden nimeämisperusteena käytettyjä keskeisiä tunnusmerkkejä. Utooppiset puhuntatavat ovat kielen puheavaruudesta ilmeneviä tapoja puhua tietyistä asioista, joihin sisältyy kunkin puhuntatavan luotettavuutta kyseenalaistava aines, puhuntakohteesta välitetyt mielikuvat ja suostuttelutarkoitus. Kutakin näistä kolmesta piirteestä voi olla kussakin utooppisessa puhuntatavassa useita. Utooppisia puhuntatapojakin saattaisi löytyä enemmän muunlaisesta aineistosta, sillä haastateltavat asiantuntijat osaavat vältellä asemaansa soveltumatonta puhuntaa. Kuvaamani utooppiset puhuntatavat edustavat vain yhtä mahdollista, mutta perusteltua tapaa jäsentää haastateltavien puhetta. Nostan niistä esille aineiston tarkastelusta erityisesti paljastuneet. Tuon niistä vastaavasti esille yhden tai kaksi keskeistä luotettavuusongelmaa sekä kuvailen kunkin sisältämän yksittäisen aluemielikuvan ja suostuttelutarkoituksen. Seuraavaksi kuvailen kunkin utooppisen puhuntatavan keskeisiä piirteitä, jonka jälkeen osoitan ne haastateltujen puhenäytteissä.

\section{Utooppiset puhuntatavat}

Raakamekanistinen puhunta antaa alueesta vaikutelman kuin se olisi monimutkainen, mutta ymmärrettävä mekaaninen laite, jonka osasia ihmisetkin ovat. Alue mielikuvitetaan koneena, joka on loogisesti vuorovaikuttavien osiensa summa ja toimittaa välinearvollista 
tehtävää. Mielikuva alueesta koneena ja välineenä onkin tässä puhuntatavassa kiistanalaista. Alueen tarkastelu mekaanisena laitteena ei ole ennakkoluulotonta, eikä yksistään riitä sen kokonaisvaltaiseen kehittämiseen. Kaikkea, kuten perimmäisiin asioihin liittyviä arvokysymyksiä, ei voida ratkaista mekaanisella välineajattelulla. Raakamekanistisella puhunnalla on hyvätahtoinen tarkoitus. Sen välittämä aluemielikuva pyrkii uskottelemaan, että alueita voidaan parantaa pelkän järjen voimalla. Se kuitenkin jättää kolkon vaikutelman aivan kuin mitkä tahansa ongelmat, esimerkiksi historiallisesti muotoutuneet, sosiaalisesti merkitykselliset ja poliittisesti kiistanalaiset, olisivat mekanistis-rationaalisesti ratkaistavissa. Tämä puhuntatapa ei ole innostava, sillä alueesta annettu mielikuva tunteettomana koneena ei vetoa tunteviin ihmisiin, joita varten alueita kehitetään.

Alueen hyödyntämättömästä tilaisuudesta puhutaan muutosmyönteisillä sanoilla kuten mahdollisuus, visio tai idea. Muutosmyönteisen puhunnan sanavalinnat ovat utopian positiivisia kiertoilmauksia toistaiseksi olemattomasta edistyksestä ja tulevaisuudessa (vrt. Levitas 2010). Tätä puhuntaa kuulee kaupallisessa markkinoinnissa sekä kansalaisten elämää parantamaan lupautuvissa poliittisissa puheissa. Muutosmyönteinen puhunta usein peittelee antiutooppista puoltaan. Se saattaa esittää niin vahvaa uskoa toivottuun muutokseen, että vertautuu Ernst Blochin (1986, 198) luonnehtimaan parempaan maailmaan sokeasti uskovaan militanttiin optimismiin. Muutosmyönteisen puhunnan toiveikas muutosinto synnyttääkin alueesta mielikuvan vaivatta yhteistyöhön suostuvien uudistajien kokeilualueena, jossa erimielisyyksiä ei tunneta. Puhuntatavassa kiistanalaista onkin muutoksen vaivattomuus ja hyödyllisyys. Alueiden uudistaminen on harvoin vaivatonta ja tasapuolista, sillä muutosvastarinnaksikin kutsuttu asiaa koskeva erimielisyys ei välttämättä murru helposti. Muutosmyönteisen puhunnan mielikuva avoimesti uudistuksia vastaanottavasta alueesta suostuttelee irtautumaan alueen perinteistä. Se on mielialaa kohottavaa puhuntaa, jonka uskottavuutta heikentää perusteeton positiivisuus ja taipumus piilottaa alleen erimielisyyttä ja eturistiriitoja.

Säilyttämistahtoinen puhunta kumpuaa muutoshaluttomuudesta ja pyrkii säilyttämään tärkeäksi koettua usein tunnesyistä. Tällä puhuntatavalla varjellaan esimerkiksi alueen kulttuuriarvoja, mutta saatetaan puolustaa myös kannattamatonta liiketoimintaa perinteisiin vetoamalla. Alueesta annetaan mielikuva menneisyyttään kunnioittavana perinteiden vaalijana pyrkimyksenä hidastaa tai pysäyttää perinteille uhaksi koettu muutos. Säilytystahtoinen puhunta aiheuttaa herkästi negatiivisen mielikuvan, jos muutosvastaisuus on vahvaa ja kohdistuu tärkeisiin uudistuksiin. Silloin se vaikuttaa kaikkien muutosten vastustamiselta, vaikka vastustaa ainoastaan uhaksi koettuja muutoksia. Tämä puhuntatapa ajautuu vastatusten muutosmyönteisen puhunnan kanssa. Säilyttämistahtoisessa puhunnassa uhaksi koetusta muutoksesta puhutaan utopian negatiivisilla kiertoilmauksilla päinvastoin kuin muutosmyönteisessä puhunnassa (vrt. Levitas 2010, 3-6). Säilyttämistahtoisen puhunnan luotettavuusongelmat ovatkin säilyttämishyötyjen paisuttelu ja muutostarpeen vähättely. Muutoksen uskotellaan johtavan huonoihin seurauksiin.

Kaukainen tulevaisuus on harvoin ensimmäisenä mielessä, koska sitä ei olla kokemassa (vrt. Bloch 1985, 29-31). Etäiseen tulevaisuuteen, kuten alueen tilanteeseen sadan vuoden päästä, kuitenkin kohdistuu uteliaisuutta. Kaukoarvaileva puhunta välittää tuota uteliaisuutta kuin pystyisi vilkaisemaan, miltä alueen hallinto, elinkeinoelämä ja asukkaiden arki näyttävät kaukaisessa ajassa lukemattomin eri vaihtoehdoin. Kaukoarvaileva puhunta muistuttaa kaikilla valinnoilla olevan arvaamattomia seurauksia ja saattaa esittää tulevaisuuden vaihtoehdot positiivisina, negatiivisina tai neutraaleina. Kaukaista tulevaisuutta arvaileva puhuntatapa välittää mielikuvan monien vaihtoehtojen arvaamattomasta alueesta. Se saattaa saada alueen tulevaisuuden kuulostamaan ruletilta, jossa sattumalla on tunnustettua suurempi merkitys. Tämä puhunta ei edustakaan systemaattista tulevaisuuden ennustamista. Se on vaistomaista ja mielikuvituksenkin värittämää pikapäättelyä nykyisyyden ja menneisyyden havainnoista. Kaukoarvailevan puhunnan kiistainalaisuus on tulevaisuuden esittäminen tyystin arvauspelinä kuin kaikki vaihtoehdot olisivat yhtä todennäköisiä. 
Sanavalinnat viestittävät toisinaan itsevarmaa ehdottomuutta. Ehdottomuusvimmaisella puhunnalla annetaan vaikutelma ainoaan oikeaan vaihtoehtoon uskomisesta. Sillä ylistetään oikeana pidettyä vaihtoehtoa vähätellen muita jopa niin hartaasti, että kuulostaa kuin muita vaihtoehtoja ei olisi. Tämän puhunnan koskiessa alueita syntyy mielikuva kuin esimerkiksi kunnan tulevaisuuden määräisi yksi ylivertainen vaihtoehto, joka valtaa alueen muilta vaihtoehdoilta. Ehdottomuusvimmaisen puhunnan kiistanalaisuus onkin ehdottomuuden harhassa. Alueen tulevaisuuteen vaikuttavien kilpailevien vaihtoehtojen häviäminen on epätodennäköistä. Ehdottomuusvimmainen puhunta saattaa kuulostaa epämiellyttävältä jääräpäisyydeltä. Se kuitenkin viestittää, että jotain aiotaan toteuttaa aikaansaamisen tahdolla (vrt. Bloch 1986, 46) ja saattaa viehättää tahdonvoiman ihailijoita. Ehdottomasti puhuminen lupaa, että ylivertaisena esitettyä alueiden kehittämisen vaihtoehtoa myös aiotaan tavoitella menestyksellä.

Puhetta käytetään toisinaan kuvittelemaan, että jollakulla olisi rajaton mahti tai monivertaisesti enemmän valtaa vaikuttaa alueen tulevaisuuteen kuin tosiasiassa on. Rajattomuuseläytyvä puhunta korottaa puhujan vaikutusvallan epärealistisen korkeaksi, jopa kaikkivoivaksi. Sen kiistanalaisuus on helposti havaittava vaikutusvallan liioittelu. Rajattomuuseläytyvä puhunta kuulostaa kuin alue tottelisi tyrannin käskyjä, mikä ei ole tarkoitus. Tämän puhunnan tuottaman mielikuvan toteutumiseen ei tosissaan uskota. Siten viestitetään turhautuneisuutta kyvyttömyyteen kehittää aluetta toivotulla tavalla. Esimerkiksi hallinnolliset rajoitteet syrjään työntävä puhunta kuulostaa epäuskottavalta. Äärimielikuvista on kuitenkin hyötyä alueen tulevaisuuden vaihtoehtojen seurausten kuvittelemisessa ja huomion hankkimisessa, esimerkiksi hallinnollisten rajoitteiden aluekehitysvaikutuksien osoittamisessa. Kehollisista rajoituksista vapautumisen kaipuu (Geras 2000; Lakkala 2014, 92) selittää rajattomaksi eläytyvää puhuntaa. Kuvitteleminen todellisia voimavarojaan mahtavammaksi vertautuu myös ajatuskokeeseen (ks. Suvin 1997, 126-128), jonka ei aidosti uskota toteutuvan.

Puhunnasta on toisinaan tunnistettavissa selittämätöntä uskoa parempaan tulevaisuuteen. Satumaakaipuinen puhunta kuulostaa hartaalta uskolta valoisaan tulevaisuuteen ilman tosiasiallisia takeita. Tällainen puhunta herättää mielikuvan kuin alueen parempi tulevaisuus toteutuu ihmeen tavoin uskomalla sen toteutumiseen. Satumaakaipuisuudesta on kyse, kun sanotaan uskottavan parempaan tulevaisuuteen, mutta uskoa ei perustella järkisyin. Järkiperusteiden puuttuminen on puhuntatavassa kiistanalaista. Satumaakaipuista puhuntaa selittää uskonnollisuuteen kallistuva pelastuksen odotus (mm. Bloch 1986) ja tarve irtautua rajallisuuden kahleista (Geras 2000; Lakkala 2014, 92). Tässä puhunnassa on positiivista tulevaisuuden odotusta kuten muutosmyönteisessä puhunnassa, jota tarvitaan raskaiden koettelemusten hetkinä. Satumaakaipuiset sanat lohduttavat, kun usko järjen voimaan ehtyy katastrofien ja maailmanlaajuisen koronapandemian aikana. Tämä puhunta muistuttaa, että aluekehittämistä tehdään tulevaisuudesta huolestuneiden ihmisten takia.

\section{Utooppinen puhunta haastatteluaineistossa}

Haastatteluaineistosta löytyi näytteitä, joissa asiantuntijat osoittavat raakamekanistisen puhunnan piirteitä tai kritiikkiä. Ensimmäisessä näytteessä raakamekanismia kritisoidaan pitämällä uhkana objektiivista suhtautumista kuntien kehittämiseen. Näytteessä asiantuntija sanoo, että hänestä kuntia ei tulisi kohdella vain suuremman kokonaisuuden osina kuten valtion säädellessä kuntien roolia omien tavoitteidensa mukaisesti. Kritiikki osuu raakamekanistisen alueista puhunnan sisältöön, joka antaa vaikutelman, että ihmisetkin voidaan alistaa ylhäältä tulevia käskyjä toimeenpaneviksi automaateiksi niin kuin he olisivat mekaanisen "aluekoneen" laitteisto-osia. 
Kahdessa muussa näytteessä raakamekanistinen puhunta näyttäytyy luonnehdittaessa kaupunkien ja maaseudun välistä suhdetta tietyillä kehityksen mittareilla nolla-summapeliksi sekä suhtautumisessa epäuskoisesti maaseutumaisten kuntien mahdollisuuksiin hoitaa tulevaisuudessakin niille tällä hetkellä kuuluvia tehtäviä. Nämä haastateltavat tietävät, että "kokonaisuuden etu" tai kuntien "inhorealistinen" tehtävien karsiminen eivät ole yksimielisiä tosiasioita. Voidaan olla monta mieltä siitä, mistä näkökulmasta kokonaisuuden etu määritellään ja mitkä kuntien tehtävät ovat säilyttämisen arvoisia. Molemmissa sitaateissa ilmenee raakamekanistinen suostuttelu, joka kehottaa kuuntelemaan instrumentaalista järjen ääntä ja uskomaan, että alueita kehitettäessä joudutaan toimimaan tiettyjen realiteettien sanelemana. Tämä tarkoittaisi joidenkin kuntien joutuvan luopuvaan niille kuuluneista tehtävistä tai hyväksymään muuttotappiot.

"Markkinavoimien vetämänä yhdyskunnat kehittyvät ja siinä on väestön liikekeen tasolla, munttoliikekeen tasolla, tällainen objektiivinen nollasummapeli-tilanne. Eri intressien tilannetta pitäisi bälventää bakemalla kokonaisunden etu. Siihen liittyy ilman munta, että ibmiset työllistyvät ja siihen liittyy kaupungistuminen jossain määrin. Siihen objektiivisen tai siis kokonaisunden etunn.” (H3)

"Kyl mä oon inhorealistinen kuntien tebtävien kannalta, varsinkin jos katsotaan maaseutumaisia kuntia. Toki eri asia voi olla suuremmissa kaupungeissa, että siellä voikin sitten olla ihan omiakin elinkeinotyöllisyysasioita. Sillä tavalla näen sen, että eri kunnat hoitavat erilaisia tehtäviä.” (H9)

Muutosmyönteinen puhunta alueista näyttäytyi kolmen eri haastateltavan puhenäytteissä. Nämä haastateltavat haluavat osoittaa kuntien pystyvän kehittämään organisaatiotaan tarttumalla toistaiseksi hyödyntämättömään tilaisuuteen. Tilaisuudella tarkoitetaan kunnan strategista valintamahdollisuutta kehittää toimintaansa, johon viitataan joko käyttäen sanaa "mahdollisuus", "radikaali" tai "visio." Nämä utopialle läheiset merkitsijät viittaavat kuntaan alueena, jota ne eivät vielä ole, mutta joksi ne voivat tulla tekemällä nykyhetkenä oikeita valintoja. Näissä puhenäytteissä kuuluu usko positiiviseen kehitykseen, joissa kunta ja niiden laajempi yhteiskunnallinen toimintaympäristö ovat avoimena muutosten käyttöön ottamiselle, jos niihin vain uskalletaan tarttua. Muutosmyönteisen puhunnan luotettavuusongelma näkyy ensimmäisessä ja kolmannessa sitaatissa. Kuntien uudistamiseen tarvittavan muutoshalun omaksuminen saadaan kuulostamaan vaivattomalta. Alueen tulevaisuus nähdään avoimena muutosten toteuttamiselle, jos vain uskalletaan olla rohkeita ja irtautua vanhoista ajattelumalleista.

"Mahdollisunksia on. Kyse on siitä, että osataanko kunnan johdossa sekë ammatillisessa ja poliittisessa johdossa vain ajatella toisin ja ottaa mabdollisundet käyttöön.” (H9)

"Vältytään elinvoimatehtävän strategisen tehtävän päällekkäisyydeltä tai sitten se on korjattu silloin. Se on vältetty tai korjattu tulevaisundessa. Tällaisen vision näen." (H3)

"Se, että kun uskalletaan radikaalisti miettiä koko paketti undestaan, nïn on saavutettavissa ja on mahdollista tuottaa kilpailukykyisillä binnoilla palveluita pienessäkin kunnassa." (H7)

Ensimmäisessä näytteessä alapuolella haastateltava ei usko kunnanviranhaltijoiden toivovan kuntalaisten osallistumista päätöksentekoon niin paljon kuin luullaan. Kasvaneen osallisuuden pelätään aiheuttavan lisätyötä. Haastateltava uskoo kunnanviranomaisten haluavan säilyttää perinteisiä päätöksentekotapoja, joiden muuttamiseksi kuntalaisia osallistavammiksi viranhaltijat eivät tee ainakaan liikaa työtä. Aiheutuu tahaton mielikuva kunnista perinteiden vaalijoina, jotka eivät halua muuttua. 
"Jos sanon suoraan, niin ei! Ei ne toivo! Kyllähän tietysti viranhaltijatkin kunnissa on usein aika työkuormittuneita, mutta jos asukekaat alkavat liikaa osallistua, nïn kyllähän se näbdään sitten päätöksenteon ja valmistelun sekä joustavunden ja eteenpä̈n menemisen näkökulmasta buonona asiana. Se bidastaa." (H4)

"Kyllähän se on sunri riski, että kunta vain kebittää kaikennäkö̈istä digitalisaatiota, digitalisoituja objelmia ja palveluprosesseja ja sinä vain läppärin kautta hoitelet asioita, nïn ei... Virtuaalikunta on semmoinen peikko. Ehkë se sadan vuoden päästä voi olla, mutta en haluaisi uskoa siihen.” (H9)

"No, sïnä on ehkä vähä mopo karannut käsistä, kun on lähdetty ajattelemaan, että kunta vois olla virtuaalinen ja vain verkossa." (H3)

Keskimmäisessä yläpuolisista sitaateista säilyttämistahtoisen puhunnan muutosvastaisuus tuottaa kunnasta mielikuvan alueena, joka vastustaa pitkälle edennyttä digitalisaatiota. Pitkälle edenneen digitalisoinnin tuomia etuja alueelle ei mietitä vaan ne esitetään lähtökohtaisesti taantumana. Virtuaalikuntaa mahdollisesti johtavaa tietotekniikan edistystä pidetään uhkaavana "peikkona", koska sen pelätään vähentävän yhteisöllisyyttä kuten kasvotusten tapahtuvaa sosiaalista vuorovaikutusta. Virtuaalikunnan nimittäminen peikoksi on keveää pelottelua ja kunnan virtualisoitumiseen johtavan kehityksen vastustamista. Syntyy mielikuva alueen virtuaalikuntakehityksen pysäyttämisestä, ettei se etene niin pitkälle kuin rajoituksitta voisi. Haastateltava ei halua uskoa pitkälle edenneeseen virtuaalikuntaan ja pyrkii mahdottomuuteen vetoamalla suostuttelemaan sen hidastamiseen tai jopa pysäyttämiseen.

Alimmassa yläpuolisista sitaateista virtuaalikuntaa ei vastusteta haitallisten sosiaalisten vaikutusten vuoksi. Haastateltava ei vain usko kuntaan erillään fyysisestä todellisuudesta. Hän käyttää säilyttämistahtoisen puhunnan tuntomerkkiä, vastustettavan asian luonnehtimista utooppiseksi, tyrmätäkseen pelkästään tietoverkossa toimivan kunnan toteutumisen sanoessaan virtuaalisen kunnan mahdollisuuteen uskovilta "mopon karanneen käsistä”. Puhunnan säilyttämistahtoisuudesta huolimatta virtuaalisuus ei välttämättä johda sosiaalisen vuorovaikutuksen katoamiseen tai merkittävään vähenemiseen. Ei myöskään varmuudella tiedetä, voiko kunta lakata olemasta muiden syiden takia. Kukaan ei tiedä, minne teknologinen kehitys esimerkiksi robotiikassa johtaa. Kuntien olemassaololle on vahvat kulttuurilliset ja historialliset perusteet, jotka eivät kuitenkaan tee kunnista välttämättömiä toisin kuin säilyttämistahtoinen puhunta antaa ymmärtää.

Ehdottomuusvimmainen puhunta näyttäytyi haastatteluaineistossa harvoin. Haastateltavat osasivat asiantuntijaroolissaan vältellä tällaista puhuntaa tietoisina kuntakehittämisen vaihtoehdoista. Asiantuntijuuskaan ei häivyttänyt kokonaan lausahduksia, jotka kuulostavat kuin kunnilla ei olisi tietyissä tilanteissa kuin yksi vaihtoehto. Alla olevassa sitaatissa on esimerkki puhunnasta, jossa sanojen voidaan tulkita viestittävän, että kuntien pitäisi omaksua samat kehittämisen suuntaviivat kuin muita vaihtoehtoja ei olisi tai ne olisivat vääriä. Syntyy mielikuva yksipuolisesta kuntarakenteesta, jota oikeana pidetty vaihtoehto hallitsee. Näin lausunut asiantuntija on tietoinen muista vaihtoehdoista sekä siitä, ettei hänen kannattama vaihtoehto ole oikea muiden mielestä. Vahva näkemys alue- ja kuntarakenteen tulevaisuudesta voi kuitenkin kuulua sanoina, jotka vaikuttavat muita vaihtoehtoja vähättelevältä jääräpäisyydeltä (vrt. Bloch 1986, 46). Haastateltava kuitenkin kuulostaa kannattamansa aluemielikuvan luotettavalta toteuttajalta. Näytteen toisessa osassa sama puhuja tunnustaakin muut vaihtoehdot asiayhteyden vaihtuessa.

"Meillä tulisi olla yksi vahva näkemys ja visio siitä, mitä tässä tapanksessa, meidän aluerakenne ja kuntarakenne ja sen suunnat ovat... [mutta kuitenkin] Sitä helposti halutaan tebdä yksinkertaistamalla vastak.kainasettelua ja sitten kuitenkin paljastuu, että maailma on byvin ybteen kietoutunut, ja sellaista vuorovaikutusta erilaisilla tasoilla kuitenkin on." (H6) 
Seuraavassa sitaatissa on vastaava esimerkki, jossa haasteltava ensin kritisoi muiden, tässä tapauksessa kunnan luottamushenkilöiden, ehdottomuutta tuottavaa puhuntatapaa. Haastateltava kuitenkin osoittautuu eri asiassa yhtä ehdottomaksi vaatiessaan pieniltä kunnilta haluamiaan toimenpiteitä välittömästi kuin ne olisivat ainoa keino pelastaa kunnat ahdingolta. Sanavalinnoista välittyy mielikuva kuin kunta olisi alue, jonka on ehdottomasti omaksuttava mainitsematta jätetty toimintamalli, jos se aikoo selviytyä. Tässä sitaatissa on muutosmyönteisenkin puhunnan piirteitä, mutta ei muutosmyönteisten sanojen käyttöä. Esitetty vaihtoehto nähdään ehdottomuusvimmaiselle puhunnalle tyypillisenä pakkotilanteena.

"No mä olin ybdessä tilaisundessa, jossa oli paljon luottamushenkilö̈tä, nün he vaativat, että jokaisella kunnalla pitää olla kiintiöpaikka. Itse en tietenkään ajattele nä̈n.” (H4)

"Nyt on pakeko saada muntosta tähän perinteiseen toimintatapaan ja ihan oikeasti läbteä ennakkoluulottomasti toimimaan ja bakemaan niitä uusia reittejä toimia." (H4)

Kaukoarvailevan puhunnan tunnusmerkit, kuten välittyvä mielikuva kysymysmerkkien alueesta, täyttyvät yhdessä seuraavista kolmesta puhepoiminnassa, kun kahdessa muussa kyseistä puhuntatapaa kritisoidaan. Ensimmäisessä näytteessä arvaillaan, millaiseksi kunta on muuttunut kaukaisessa tulevaisuudessa ainakin sadan vuoden päässä. Niin kaukaisen kunnan hallintoa arvioidaan sanalla "ehkä", mikä osoittaa etäiseen tulevaisuuteen kurkistamisen arvailuluonteen. Arvailuun valkopukuisen miesraadin johtamasta kaukaisesta tulevaisuuden kunnasta sekoittuu ironian sävyttämiä piirteitä tieteiselokuvistakin. Tietämättömyys kaukaisista tapahtumista tulee ilmi. Arvailun voi perustaa vain nykyhetken ja menneisyyden havaintoihin, jotka helposti pettävät monen muuttujan vaihdellessa pitkällä aikavälillä. Alueista vuosisatojen kuluttua puhunnalla välitetyt mielikuvat ovat epäluotettavia saattaen kuulostaa kuin alueiden tulevaisuudesta ei voitaisi tietää mitään.

"Onko se kunta sitten vaan tämmöinen virtuaalikunta? Ehkä siellä joku raati on nïn kuin jossain byvissä tieteellisissä elokuvissa. Siellä on aina ne valkoisiin pukeutuneet kymmenen miestä, jotka tekevät tärkeimmät päätökset. Ehkä se (virtuaalinen kunta) sadan vnoden päästä voi olla tullut nykyisestä.”

Kaksi haastateltua kritisoi alueiden tulevaisuuden esittämistä kysymysmerkkeinä, koska alueiden tulevaisuutta ei voida suunnitella arvauksilla. Nykyhetken ennusmerkit eivät ole riittäviä, jotta tiedettäisiin, mitä kaukaiset ajat tuovat tullessaan. Tuskin päädytään juuri kymmenestä valkoasuisesta miehestä koostuvan raadin johtamaan tietoverkkoon siirtyneeseen kuntaan, mutta jonkun kuntien tehtäviä täytyy kaukaisessa tulevaisuudessakin ohjata. Arvailu alueiden hallinnon muuttumisesta pitkien aikojen kuluessa ei ole perusteetonta. Mielikuvilla alueen tulevaisuudesta kysymysmerkkinä pystytään lisäksi rohkaisemaan vaikeiden valintojen tekemiseen, koska kaikki valinnat ovat osittain arpapeliä. Parisataa vuotta sitten harva kykeni ennustamaan Suomeen perustettavan merkittäviksi toimijoiksi kehittyviä aluehallintorakenteita nimeltä kuntia, vaikka signaaleja saattoi jo olla.

"Jos nykyisistä heikoista signaaleista vetäisi trendiä johonkin sadan vuoden päähän, niin silloin sellainen maailma on mahdollinen, jossa ihmiset eivät enää kobtaa toisiaan fyysisesti.” (H2)

"Sanon nyt vähä jyrkästi, että se on kuitenkin näitten, kun me tehdään 20-30 vuoden täbtä̈mellä, nün organisaatioita ja kehitetään toimintoja, nün mä näen, että niin pitkeälle menevät asiat on epärelevantteja." 
Yhden haastateltavan sanojen käyttö muistutti rajattomuuseläytyvää puhuntaa. Tietoisena rajallisuudestaan hän kuvitteli itsensä asemaan, jossa on saanut vallan päättää kunnan tulevaisuudesta riippumamatta muiden mielipiteistä. Kuvitelmassa voimistuneella vallalla kuntien rakenteet, rajat ja tehtävät muutetaan vastaamaan omia toiveita. Haastateltavan eläytymä kuvitteellinen tilanne alueesta on mielikuvana tyrannimainen yhden henkilön päättäessä muiden asioista. Kuvitelmassa henkilökohtaisen vallan voimistumisestakin näkyy, etteivät sen tarkoitusperät ole itsekkäitä, sillä kuvitelmassa alueiden yleishyödylliset sosiaalipalvelut ja terveyshuolto ovat edistyneet. Ajatuskoetta (Suvin 1997) muistuttava kuvitteellinen tilanne ei voi toteutua, mutta aluekehittämisen vaihtoehtojen seurauksia ymmärretään paremmin eläytymällä aluetta käskyttäväksi itsevaltiaaksi. Lisäksi kärjistykset hankkivat huomiota aluekehittämisen visioiduille vaihtoehdoille.

"Jos vois olla Suomen itsevaltias, eikä tarvitsisi välittää, mitä seuraavissa vaaleissa kä̈, niin vois olla, että tämä maakuntajako alkaisi pian vastata monella muullakin alueella palveluvastuita kuin vain sosiaali-ja terveyspalveluissa." (H7)

"Jos olisin Suomen diktaattori, nïn sitten ei olisi kuntia, vaan meillä olisi kaupunginosavaltuustot ja maakuntavaltuustot. Mä olisin tämän kuntatason eliminoinut sïtä välistä kokonaan.” (H7)

Satumaakaipuinen puhunta näyttäytyi asiantuntijoiden arvioidessa, onko kuntien tulevaisuus valoisa vai synkkä. Alapuolisissa näytteissä on satumaakaipuisalle puhunnalle tyypillistä selittämätöntä uskoa alueiden parempaan tulevaisuuteen. Tämä ei tarkoita, etteivät asiantuntijat osaisi perustella uskomuksiaan. Perusteluissakin kuitenkin on perustelematonta uskoa, jossa alueiden paremman tulevaisuuden palikkojen ajatellaan vain loksahtavan kohdilleen. Valituissa näytteissä haastateltujen sanoissa ilmenee Blochin (1986, 45-46) kuvailema puhtaan uskon kaltainen kaipuu kohdistettuna parempaan kuntaan.

"Sïs kyllähän maailman merkit tietysti alkeavat byvin huolestuttavilta tällä hetkellä näyttää, mutta siitäkin buolimatta mä näen tulevaisunden aina valoisampana." (H6)

"Mä oon sïs ihan ibmeen teknoutopisti, joten uskon, että se (tulevaisuns) on valoisa. Enemmän pelkään ilmastonmuntoksen romahduttavan systeemin kuin kuntaundistuksen." (H7)

'Tylsä vastaus, sekä-että! Varmaankin tulee tämä erilaistumiskehitys. Se tulee voimistumaan, sille ei mahda mitään. Kyllä kuitenkin olen optimisti. Luotan, että näitä undenlaisia tapoja tebdä ja toimia löytyy, jos ei muntoin nïn pakon edessä.” (H4)

"Haluan uskoa, että se on valoisa. Haluan uskoa siihen, että läbidemokratia löytää unsia tapoja ja ibmisten aktiivisuus ja halu osallistua osataan ottaa paremmin buomioon." (H8)

Ensimmäisessä näytteessä huolet kuntien kohtaamista globaaleista uhista eivät horjuta uskoa parempaan tulevaisuuteen. Sama puhunta toistuu toisessa ja kolmannessa näytteessä, jossa teknologian kehityksen uskotaan ratkaisevan vaikeatkin haasteet. Kolmannessa näytteessä tulevaisuudessa odotetaan kohdattavan yhtä paljon haasteita kuin nytkin, mutta silti usko parempaan säilyy. Sama toistuu neljännessä näytteessä, jossa "vain halutaan”, että keinot aktivoida kuntalaisia kunnan kehittämiseen toimivat tarkempia perusteita vaatimatta. Näytteet osoittavat, että kunnista puhutaan välittäen selittämätöntä uskoa, jossa alueesta välitetään mielikuvaa kuin sen puuttuvat tarpeet täyttyisivät kuin ihmeenä. Ihmettä tuskin tapahtuu, mutta voimakas usko ihmeisiin ylläpitää alueiden uskoa tulevaisuuteen. 
Taulukko I. Utooppiset puhuntatavat esimerkkeineen niihin sisältyvistä luotettavuusongelmista, aluemielikuvista ja suostuttelutarkoituksista.

Table I. Utopian talking types and their reliability problems, imagined region and persuasion purpose.

\begin{tabular}{|c|c|c|c|}
\hline $\begin{array}{l}\text { Utooppinen } \\
\text { puhuntatapa }\end{array}$ & $\begin{array}{l}\text { Luotettavuus- } \\
\text { ongelma }\end{array}$ & Aluemielikuva & Suostuttelutarkoitus \\
\hline Raakamekanistinen & $\begin{array}{l}\text { Usko välinearvoihin ja } \\
\text { niiden neutraaliuteen }\end{array}$ & $\begin{array}{l}\text { Osiensa loogiseksi } \\
\text { kokonaisuudeksi } \\
\text { viritetty aluekone }\end{array}$ & $\begin{array}{l}\text { Alueen kehittäminen } \\
\text { järkeä ihannoiden }\end{array}$ \\
\hline Muutosmyönteinen & $\begin{array}{l}\text { Muutoksen vaivatto- } \\
\text { muus ja hyödyllisyys }\end{array}$ & $\begin{array}{l}\text { Yhteistyöhaluisten } \\
\text { uudistusmielisten } \\
\text { kokeilualue }\end{array}$ & $\begin{array}{l}\text { Alueen rohkea } \\
\text { uudistaminen }\end{array}$ \\
\hline Säilyttämistahtoinen & $\begin{array}{l}\text { Muutostarpeen } \\
\text { pienenteleminen } \\
\text { ja säilytystarpeen } \\
\text { suurenteleminen }\end{array}$ & $\begin{array}{l}\text { Menneisyyttä } \\
\text { kunnioittava } \\
\text { perinteiden alue }\end{array}$ & $\begin{array}{l}\text { Alueuudistuksen } \\
\text { pysäyttäminen tai } \\
\text { hidastaminen }\end{array}$ \\
\hline Kaukoarvaileva & $\begin{array}{l}\text { Tulevaisuuden } \\
\text { arvaamattomuuden } \\
\text { liioitteleminen }\end{array}$ & $\begin{array}{l}\text { Loputtomien } \\
\text { kysymysmerkkien } \\
\text { alue }\end{array}$ & $\begin{array}{l}\text { Alueen vaihtoehtojen } \\
\text { tiedostaminen ja } \\
\text { vaikeisiin valintoihin } \\
\text { rohkaiseminen }\end{array}$ \\
\hline Ehdottomuusvimmainen & $\begin{array}{l}\text { Vaihtoehdottomuuden } \\
\text { harhaisuus }\end{array}$ & $\begin{array}{l}\text { Ylivertaisen valinnan } \\
\text { aluevalloitus }\end{array}$ & $\begin{array}{l}\text { Alueen tavoitteiden } \\
\text { saavuttamisesta } \\
\text { vakuuttaminen }\end{array}$ \\
\hline Rajattomuuseläytyvä & $\begin{array}{l}\text { Vaikutusvallan paisutte- } \\
\text { leminen }\end{array}$ & $\begin{array}{l}\text { Suvereenin } \\
\text { itsevaltiaan } \\
\text { käskyalue }\end{array}$ & $\begin{array}{l}\text { Alueiden valintojen } \\
\text { seurausten hahmot- } \\
\text { taminen ja huomion } \\
\text { hankkiminen }\end{array}$ \\
\hline Satumaakaipuinen & Järjellä selittämättömyys & $\begin{array}{l}\text { Uskolla syntynyt } \\
\text { ihmealue }\end{array}$ & $\begin{array}{l}\text { Alueen tulevaisuususkon } \\
\text { ylläpitäminen }\end{array}$ \\
\hline
\end{tabular}

\section{Johtopäätökset}

Utooppiset puhuntatavat selittävät aluekehittämistä kielenvaraiseen vuorovaikutukseen perustuvana toimintana, jossa alueiden tulevaisuuteen vaikutetaan suostuttelevilla aluemielikuvilla niiden sisältämien luotettavuusongelmien varjostamana (Taulukko 1). Puhunnan välittämien aluemielikuvien luotettavuusongelmassa on kyse alueesta annetusta karkeasta yleiskuvasta, jossa joitain sen piirteitä liioitellaan ja toisia vähätellään tai jopa kuvitellaan kadoksiin. Aluemielikuvien suostutteluvoima perustuukin siihen, ettei niiden luotettavuusongelmaa tunnisteta, tai sitä ei pidetä niin merkittävänä, että se vaikuttaisi suostuttelutarkoitusten uskottavuuteen. Jotkut havaituista utooppisista puhuntatavoista sopivat toisia paremmin teknokraattiseen eli asiantuntijavaltaiseen kehittämiseen kuten kuntien aluesuunnitteluun ja päätöksentekoon. Osaan niistä asianmukaisen koulutuksen ja kokemuksen hankkineet asiantuntijavirkamiehet saattavat suhtautua varauksellisesti.

Raakamekanistinen puhuntatapa on yleistä asiantuntijalähtöisessä aluekehittämisessä. Asiantuntijavaltaisuuden tarkoitus ei ole kehitettävän alueen asukkaiden kohteleminen mekaanisen koneiston osina, mutta tälle puhunnalle ominaista on insinöörimäinen suhtautuminen alueen kehittämiseen. Raakamekanistinen puhunta on osa teknokraattista aluekehittämistä, joka keskittyy tiettyyn osaan aluekehittämisen kokonaisuudesta, kuten kuntaviranomaisten tehtävien hoitamiseen kuuluvaan vastuuseen valvoa muun muassa resurssien riittävyyttä kunnan tehtävien hoitamiseksi. Kuntaan suhtaudutaan tässä viitekehyksessä vertauskuvallisena aluekoneena, jonka polttoainevarastojen riittävyydestä ja voimavarojen jakamisesta on huolehdittava. 
Muutosmyönteistä puhuntaa saatetaan vieroksua asiantuntijavaltaisessa julkishallinnossa. Alueen nykytilasta ja tulevaisuudesta puhuminen liian suurin odotuksin tulkitaan herkästi asiantuntijamaisen varovaisuuden ja vastuullisuuden puuttumiseksi. Kuntahallinnossa ollaan tietoisia riskeistä, jolloin perusteettomien positiivisten tulevaisuuspuheiden saatetaan ajatella olevan jopa julkisviranomaisen etiikan vastaista. Muutosmyönteisen puhunta myös täyttää asiantuntevan näkökulmasta laiskan ja kritiikittömän ajattelun tuntomerkit, jonka varaan alueen kehittämistä ei voida perustaa. Muutosmyönteisyys toisaalta loistaa puhunnassa kuntien rakentaessa imagoa uusien asukkaiden houkuttelemiseksi välittämällä vetoavia mielikuvia avoimesta ja uudistusmielisestä kunnasta.

Muutospaineissa, kuten SOTE-uudistuksessa, asiantuntijoiden on otettava kantaa, mistä asioista kuntien tulisi pitää kiinni. Säilytystahtoinen puhunta onkin arkea kuntahallinnossa. Jänniteitä syntyy virkamiestenkin ollessa keskenään tai vaaleilla valittujen kunnanvaltuuston edustajien kanssa eri mieltä siitä, mitä pitäisi muuttaa ja mitä säilyttää. Tarkoittamani säilytystahtoinen puhunta liittyy tunnepitoisiin perinnearvoihin, joiden suojeleminen on osa asiantuntija-aluehallinnon tehtäviä. Teknokraattinen hallintokulttuuri joskus korostaa kuntien taloudellisen toimintakyvyn merkitystä raakamekanistisella puhunnalla, mutta asiantuntijavirkamiesten täytyy joskus lainkin velvoittamana puhua säilytystahtoisesti. Alueilla on lakisääteisiä suojelutehtäviä, joiden syyt eivät ole ensisijaisesti taloudellista etua tavoittelevia. Esimerkiksi rakennusperinnön varjelun syyt ovat historian arvostamisessa.

Kaukoarvailevan puhunnan sopivuus kuntien johtamiseen ja suunnitteluun on kaksijakoinen. Vaistomaiset arvailut tulevaisuudesta eivät sovellu asiantuntijakulttuuriin, joka edellyttää tietämistä, vaikka tietäminenkin sisältää asioita, joista ei ole varmuutta. Kunnallisen viranomaisen vastuullisessa tehtävässä ei kuitenkaan voida ajatella, että tulevaisuus olisi täysin hallitsematonta arpapeliä, johon oikeita johtamisen ja suunnittelun valintoja tekemällä ei voida vaikuttaa. Kaukoarvaileminen on kuitenkin systemaattisenkin tulevaisuuden ennakoinnin esivaihe, jota kuntahallinnossakin tehdään muun muassa kehiteltäessä kuntien mahdollisia tulevaisuuksia ennustavia skenaarioita. Muutoin kaukoarvailevaan puhuntaan saatetaan suhtautua omituisena asiantuntijatiedolla ohjatuissa kunnissa. Tulevaisuudella arvuuttelu saatetaan mieltää jopa valeuutisten kaltaisiin pyrkimyksiin alentaa julkisvallan uskottavuutta.

Haastatteluaineisto osoitti ehdottomuusvimmaistakin puhuntaa kuultavan kuntien kehittämisen asiantuntijoilta. Periksi antamaton ehdottomuusvimma todennäköisesti saa nuivan vastaanoton kuntahallinnossa, jossa asiantuntijuuden tarkoituksena on tunnistaa vaihtoehtoja. Ylimielisyydeksi herkästi tulkittava puhunnan ehdottomuusvimma sopii huonosti keskustelevaan demokratiaan viestittäen uskosta vanhanaikaisiin hierarkkisiin johtamiskäsityksiin. Jokaisella asiantuntijalla ja kunnanvaltuuston jäsenellä on kuitenkin mielipiteitä kuntien kehittämisen toivotusta suunnasta, joita he pitävät muiden mielipiteitä parempina. Siksi asiantuntijakin saattaa välillä puhua kuin näkisi vain oman vaihtoehtonsa. Toisinaan ehdottomuusvimmainen puhunta saattaa olla tahatonta. Asiantuntijuus tuo mukanaan tarpeen osoittaa tietävän täsmälleen, miten tietyissä tilanteissa toimitaan. Ehdottomasti on puhuttava esimerkiksi silloin, kun laki ei mahdollista rakentamista sinne, minne toimiluvan hakija taipumatta haluaisi.

Kuntakehittämisen asiantuntijatkaan eivät välty rajattomuuseläytyvältä puhunnalta. Julkishallinnossa on silti syy suhtautua penseästi tähän puhuntatapaan. Rajattomuuseläytyvä puhunta kuten kaukoarvaileva puhunta liittyy riskinottamiseen. Periaatteessa kunnat ottavatkin riskejä tehdessään hankintoja ja kaavoittaessaan aluettaan tarkoituksiin, joiden kannattavuus ei ole taattu. Julkishallinnon kuitenkin tulisi olla tarkkaa ja harkittua verovarojen käyttöä. Kaukoarvaileva puhunta pyrkii oikeuttamaan riskin antamalla alueista mielikuvan kuin niiden kehittäminen olisi rulettia, jolloin kynnys valita riskivaihtoehto madaltuu. Rajattomuuseläytyvällä puhunnalla tuotetulla vaikutusvaltaa liioittelevalla mielikuvalla voidaan puolestaan uskotella, että tietyn henkilön johdossa kunta tai muu alue pystyy mihin tahansa ja voi ottaa riskejäkin. Toisaalta rajattomuuseläytyvä puhuntakin 
voi toimia kuntaimagon luomisessa antamalla kunnasta mielikuva elämää suurempana asuinpaikkana. Se sopii myös skenaariomallien kehittämistyöhön innoittamaan leikkisillä visioilla.

Havaituista utooppisista puhuntatavoista viimeinen on harvinainen kuntahallinnossa. Puhuminen pelkällä haaveilevalla uskolla saavutettavasta paremmasta kunnasta alentaa herkästi kuntakehittämisen asiantuntijan uskottavuutta. Toiminnan riskit tunnistamaan pyrkivässä ja julkisvastuullisessa kuntien kehittämisessä tukeudutaan perusteltuihin valintoihin, joissa perusteettomalle uskolle on vähän tilaa. Kuntahallinnon asiantuntijatkin kuitenkin ovat tulevaisuudesta huolta kantavia ihmisiä kuten kuntien asukkaat, joiden hyväksi asiantuntemusta käytetään. Heillä on henkilökohtaisiin arvoihin perustuvia ihanteita ja asiantuntijatyössä jaksamaan auttavaa uskoa. Satumaakaipuinen puhunta ei sovellu tietotaitoa vaativaan johtamisen ja suunnittelun työhön. Poikkeuksellisista kriiseistä selviämistä ja ratkeamattomilta tuntuvien kiistojen selvittämistä voi kuitenkin edistää osapuolten muistuttaminen perimmäisitä syistä kuntien kehittämisen taustalla.

Havaittujen utooppisten puhuntatapojen perusteella alueita kehitetään ristiriitaisilla, mutta kehitystä tiettyyn suuntaan suostuttelevilla aluemielikuvilla. Ne heijastavat alueiden yhtäaikaisia tarpeita vaalia perinteitä, pyrkiä uudistumaan, vaatia tuloksia, huomioida voimavarat, ennakoida muutoksia ja uskoa hyvään tulevaisuuteen. Puhunnan utooppisuus ei ole puheavaruuden arvotonta taustahälinää, vaan puhunnan aluemielikuvat ovat aluekehittämisvälineitä, joilla vaikutetaan kunnalliseen päätöksentekoon ja julkisuuskuvan rakentamiseen, ellei jopa ratkaista, millaiseen tulevaisuuteen alueita kuljetaan. Utooppisella puhunnalla on ainakin kahdenlaisia kuntia hyödyttäviä käyttötarkoituksia. Taito ymmärtää ja hyödyntää sitä antaa kunnalle edun alueiden välisessä kilpailussa. Kilpailuhyödyn lisäksi utooppista puhuntaa voidaan käyttää yhteisvastuullisesti. Mielipiteiden utooppiset sisällöt purkamalla voidaan rakentaa luottamusta ja ymmärrystä toimijoiden välille, mitä tarvitaan eri taustoista tulevien aluekehittäjien väärinymmärrysten välttämisessä. Erilaisten aluekehittämispuheiden utooppisen luonteen tai aspektin tunnistamisen tulisikin kuulua julkisvastuuseen esimerkiksi osana informaatiovaikuttamisesta valistamista.

\section{Lähteet}

Anderson, B. (2006) Transcending without transcendence: Utopianism and Ethos of Hope. Antipode 38(4) 691-710. https://doi.org/10.1111/j.1467-8330.2006.00472.x

Balasopoulos, A. (2006) Anti-utopia and dystopia: rethinking the generic field. School of Fine Arts Publications 16 59-67. https://doi.org/10.5325/utopianstudies.26.2.0383

Baeten, G. (2002) The Spaces of Utopia and Dystopia: Introduction. Geografiska Annaler, Series B, Human Geography 84(3-4) 141-142. https://doi.org/10.1111/j.0435-3684.2002.00119.x

Bloch, E. (1986). The Principle of Hope (in German). Translated by Plaice, N., Plaice, S. \& Knight, P. $2^{\text {nd }}$ ed. MIT Press, Cambridge.

Bloch, E. (1985) Ennakoitu todellisuus: Mitä on utooppinen ajattelu ja mitä se saa aikaan?'Teoksessa Rahkonen, K. \& E. Sironen (toim.): Bloch, Ernst, Utopia, luonto, uskonto, 34-40. Kansan Sivistystyön Liitto, Helsinki.

Burke, K. (1967) The Philosophy of Literary Form: Studies in Symbolic Action. University of California Press, Berkeley. Claeys, G. \& Sargent, L. (1999) Utopia reader. New York University Press, New York.

Dima-Laza, R. (2012) Utopia versus dystopia: A Perfect environment for a perfect existence. International Conference of humanity, history and society 34 12-16. http:/ / www.ipedr.com/vol34/003-ICHHS2012-H00005. pdf

Foucault, M. (1980) Questions in geography. Teoksessa Gordon, C. (toim.): Power/Knowledge: selected interviews and other writings 1972-1977 63-77. Pantheon Books, New York.

Friedmann, J. (2000). The Good City: Defense of Utopian Thinking. International Journal of Urban and Regional Research 24(2) 460-472. https:/ / doi.org/10.1111/1468-2427.00258

Geras, N. (2000) Minimum utopia: Ten Theses. Socialist Register. <https://www.marxists.org/reference/subject/ philosophy/works/us/geras1.htm>. 18.5.2020.

Gregory, D. (1996) Geographical imaginations. Blackwell, Cambridge.

Habermas, J. (1987) Theory of Communicative Action: Lifeworld and System: A Critique of Functionalist Reason. Beacon Press, Boston. 
Harvey, D. (2000) Spaces of Hope. Edinburgh University Press, Edinburgh.

Holloway, J. (2010) Crack capitalism. Pluto Press, London \& New York. https://www.jstor.org/stable/j. ctt183p362

Hyyryläinen, E., Karhu, M \& Luoto I. (2018). Tulevaisuuden kunta kehittyy organisaatioparadoksien ristiaallokossa. Focus Localis 46(1) 8-21.

Hyyryläinen, T. (2019) Utopioiden paluusta ja visioiden voimasta. Versus-lehden tiededebatti. <https://www. versuslehti.fi/tiededebatti/utopioiden-paluu-aluekehittamiseen/>. 25.2.2020.

Itkonen-Kaila, M. (1998) Thomas More ja hänen Utopiansa. Teoksessa Itkonen-Kaila, M. (toim.): Thomas More: Utopia 7-21. WSOY, Juva.

Jacoby, R. (2005) Picture imperfect: Utopian Thought for an Anti-Utopian age. Columbia University Press, Columbia.

Jameson, F. (2005) Archaeologies of the Future: the desire called utopia and other science fictions. Verso, London.

Johnson, G. (2011) Elements of the utopian. The Davies Group, Colorado.

Kallis, G. \& March, H. (2015). Imaginaries of hope: The utopianism of degrowth. Annals of the Association of American Geographers 105(2) 360-368. https://doi.org/10.1080/00045608.2014.973803

Karhu, M. (2019) Utopia, utopismi ja paikan tutkimus. Alue ja ympäristö 48(1) 117-123. https://doi. org/10.30663/ay.75179

Karjalainen, P. T. (2006) Topobiografinen paikan tulkinta. Teoksessa Knuuttila, S. Laaksonen, P. \& Piela, U. (toim.): Paikeka. Eletty, kuviteltu, kerrottu, 83-92. Gummerus, Jyväskylä.

Katajamäki, H. (2016) Aluekehittämisen sumea tulevaisuus. Terra 128(2) 95-98.

Kymäläinen, P. (2006) Paikan ajattelun haasteita. Teoksessa Knuuttila, S. Laaksonen, P. \& Piela, U. (toim.): Paikeka. Eletty, kuviteltu, kerrottu 203-217. Gummerus, Jyväskylä.

Lahtinen, M. (2017) Utopiat ja niiden vastakuvat. Futura 1 5-13.

Lahtinen, M. (2002) Matkoja utopiaan. Otavan Kirjapaino, Keuruu.

Lakkala, K. (2018) Esipuhe. Teoksessa: Mentula, M., Lakkala K. Suominen, S. \& Era, H. (toim.): Utopia työkaluna: irti vaibtoehdottomunden valheesta 6-11. Demokraattinen Sivistysliitto, Helsinki.

Lakkala, K. (2017) Utopiat yhteiskunnallisen mielikuvituksen metodologiana. Futura 1 14-21.

Lakkala, K. (2014) Utopia tänään:ybteiskunnallisen mielikuvituksen metodologiaa. Kampus Kustannus, Jyväskylä.

Latvala, P. (2006) Suvun satumailta katkeruuden kentille. Paikka kokemuksena ja tunnetilana. Teoksessa Knuuttila, S. Laaksonen, P. \& Piela, U. (toim.): Paikka. Eletty, kuviteltu, kerrottu 171-186. Gummerus, Jyväskylä.

Levitas, R. (2013) Discourses of risk and utopia. Journal of Architectural Education 67 (1) 122-128. https://doi. org/10.1080/10464883.2013.771532

Levitas, R. (2010) The Concept of utopia. $2^{\text {nd }}$ ed. Peter Lang AG, Bern.

Linnamaa, R. \& Sotarauta, M. (2000) Verkostojen utopia ja arki. Tutkimus Etelä-Pohjanmaan kehittäjäverkostosta. Tampereen yliopisto: Alueellisen kehittämisen tutkimusyksikkö. Sente-julkaisuja 7.

Lintilä, K. L. (2016) 50-vuotta aluepolitiikkaa aitiopaikalla. Terra 128(2) 98-100.

Locke, C. (2017) The real reason dystopian fiction is roaring back. Wired. <https://www.wired.com/2017/02/ dystopian-fiction-why-we-read/>. 25.2.2020.

Lundström, N. (2017) Aluekehittämisen pirullinen peli. Acta Wasaensia, Vaasa. https://www.univaasa.fi/materiaali/ pdf/isbn_978-952-476-623-4.pdf

Luoto, I. \& Karhu, M. (2018) Utopiakirjallisuus ja aluekehittämisen paradoksit. Terra 130(2) 69-81. http:// urn.fi/URN:NBN:fi-fe2019102835203

Luoto, I. (2008) Paikan tekstit ja niiden henki: Johdatus Geosemiotiikkaan - matkakertomus paikan kulttuurilliseen ytimeen. Nordia Geograpbical Publications 37(2). Multiprint Oy, Oulu.

Moisio, S. (2012) Valtio, alue, politiik.ka: Suomen tilasubteiden sääntely toisesta maailmansodasta nykypäivään. Vastapaino, Tampere.

Moylan, T. \& Baccolini, R. (2014) Demand the impossible: science fiction and the utopian imagination. Peter Lang, Bern.

Phillips, R. (1993) The Language of images in geography. Progress in Human Geography 17(2) 180-194. https:// doi.org/10.1177\%2F030913259301700203

Pietikäinen, S. \& Mäntynen, A. (2009) Kurssi kobti diskurssia. Vastapaino, Tampere.

Pietilä, V. (2004) Kaiken takana on teknologia: Harold Innis ja Marshall McLuhan tekivät välineistä viestintäteoriaa. Teoksessa Mörä, T. Salovarra-Moring, I., Valtonen, I. \& S. (toim.) Mediatutkimuksen vaeltava teoria. Gaudeamus, Helsinki.

Pinder, D. (2013) Reconstituting the possible: Lefebvre, Utopia and the Urban Question. International Journal of Urban and Regional Research 39(1) 28-45. https://doi.org/10.1111/1468-2427.12083

Portolano, M. (2012) The Rhetorical Function of Utopia: An Exploration of the Concept of Utopia in rhetorical theory. Utopian Studies 23(1) 113-141. https://doi.org/10.5325/utopianstudies.23.1.0113

Postman, N. (1985) Huvitamme itsemme hengiltä. WSOY, Helsinki.

Pylkkö, P. (2013) Ajatus ja kädet. Uuni, Taivassalo.

Sarajärvi, A. \& Tuomi, J. (2018) Laadullinen tutkimus ja sisällönanalyysi. Kustannusosakeyhtiö Tammi, Helsinki. 
Sargisson, L. \& Sargent, L. (2017). Lived Utopianism: Everyday life and intentional communities. Communal Societies 37(1) 1-24.

Seitamaa-Hakkarainen, P. (2019). Kvalitatiivinen sisällönanalyysi: sisällön analyysin keskeisiä piirteitä. Metodix. <https://metodix.fi/2014/05/19/seitamaa-hakkarainen-kvalitatiivinen-sisallon-analyysi/>. 25.2.2020.

Sargent, L. (2010): Utopianism: very short introduction. Oxford University Press, New York.

Suvin, D. (1997) Locus, Horizon and Orientation: The Concept of Possible Worlds as a key to Utopian Studies. Teoksessa Daniel, J. O. \& Moylan, T. (toim.): Not yet: reconsidering Ernst Bloch 122-137. Verso, Lontoo \& New York. http://dx.doi.org/10.1093/actrade/9780199573400.001.0001

Williams, R. (2005) Culture and materialism: selected essays. Verso, Lontoo \& New York. 